\title{
THE INTERPRETATION OF THE HOMELAND IN THE WORKS OF MUHAMMAD YUSUF
}

\section{Akram Akbarovich Khudayberdiev}

Freelance Researcher Of The Uzbek Literature Studies, Faculty Of Philology, Andijan State University, Uzbekistan

\section{ABSTRACT}

The article describes the views of works of Muhammad Yusuf on the concept of homeland, the definition of homeland, various meanings and semantic interpretations of the concept of homeland based on creative examples. The application of the concept of homeland in a narrow and broad sense is shown in the example of excerpts from poetry of Muhammad Yusuf. It is revealed that the concept of homeland acquires meaning in terms of material and spiritual connection.

KEYWORDS: - Homeland concept, Homeland, Earth, country, territory, state, place, nature, animal, human, soul.

\section{INTRODUCTION}

Ko'hna tol beshikdan boshlangan olam,

Senga iddaolar qilmay sevaman.

Bir kuni singlim deb,

Bir kuni onam -

Vatan,

Kimligingni bilmay sevaman.

(Muhammad Yusuf)

Meaning:

The world that began in the old willow cradle, I love you without making claims.

One day as my sister,

One day my mother -

Homeland,

I love you not knowing who you are.

(Muhammad Yusuf)
The poet, the writer, in general, are talented people who have the ability to express the thoughts of the creators, the truths of the soul in their works, in the eyes of Allah. That is, only a person who is able to express his feelings and experiences in his tongue and express them in his pen is considered a true creator. The works of such artists quickly find their fans because they come from the heart, the most transparent place of man - and live forever in the hearts.

We can take the work of the poet Muhammad Yusuf, who is revered by our people, as the highest example of the above ideas. After all, the poet was a creator in harmony with the heart of the pen. Whatever he wrote, he wrote from the heart, expressing it without any exaggeration. For this reason, there is no house where his poems have not entered, no one who has not listened to his melodies. 
CURRENT RESEARCH JOURNAL OF PHILOLOGICAL SCIENCES 2(8): 27-30,

May 2021 DOI: https://doi.org/10.37547/philological-crjps-02-08-07

ISSN 2767-3758

(C)2021 Master Journals

Crossref doi) 81 Google

Accepted22 ${ }^{\text {th }}$ August, 2021 \& Published 27th August, 2021

Among the wide readership and our people, it is often said that Muhammad Yusuf's poetry is "easy to read and understand, simple and sincere." Indeed, the poet's poems are read simply and fluently. But try to write like him, you can't! His seemingly easy-to-write verses make fans cry, laugh and pull him into their arms. So what was the secret to that? This question can be briefly answered as the purity and sincerity of the poet's heart. Because in order to be creative, you have to have a big and sincere heart. He must be able to truly love the people he sings, the people and the Homeland.

The main theme of Muhammad Yusuf's poetry is the glorification of human feelings such as love, affection and devotion, and the boundless love and respect for the Motherland, which is the main factor and flower of these feelings. The poet writes in the poem "Izhori dil":

Vatan - yuragimning olampanohi

Bu dunyo bukri bir jiydangning shoxi.

Ko'zim yoshi bilan sug'orib gohi,

Ko'ksimda o'stirgan gulday sevaman.

Meaning:

Homeland - the hearth of my heart

This world is horn of crooked jiida.

sometimes I water with tears in my eyes

I love it like a flower growing in my chest.

Homeland... There is no artist who has not sung it. Because for a creator there is no such joy and honor as singing the place where he was born and grew up his homeland. Although the essence of the works written on the theme of homeland is the same, but none of them is similar to each other. In this regard, we can say that the poems on the theme of the Homeland, which occupy a central place in the work of Muhammad Yusuf, are vivid and impressive due to the unique melody and unique verses. That is, in the poet's lyrics we see metaphors, parables, which no one imagined, but which correspond. We can say that such analogies do not occur in any other creative poetry, the peculiar artistic language of the poet's works. For example, none of the poets who wrote about the homeland has yet likened the homeland to a mother or a sister, or only this artist was the first to use it in his work. There are many people who sing about the gardens of the homeland, the beautiful corners. But no one sang of the homeland as "the hearth of my heart" and its "horn of crooked jiida" And we can see the metaphor of "the gold - novvot under my tongue, you are my only prophet" in the poetry of Muhammad Yusuf.

The poet explains how he loves his homeland:

Cho'ksang, tur singlim deb,

Soching silayman.

So'ksang, opam deyman,

Umring tilayman.

Sendan ranjimayman,

Gina qilmayman-

Xoh xo'mray, xoh jilmay,

Birday sevaman.

Meaning:

If you drown, I will say get up, as you are my sister, I will rub your hair.

If you punish me, I feel you as my mother,

I wish your life.

I do not upset with you,

I am not angry -

Smile or not smile,

I love always.

In our people, a real man has the qualities of protecting his mother and sister, supporting them like a mountain. Like a sister, the homeland relies on protection, on men who are like a mountain.

As mentioned above, in most of his poems about the homeland, the poet likens the homeland to a mother, a sister and a brother. For example, in the poem "My Homeland":

Shodon kunim gul otgan sen,

Chechak otgan izimga, 
CURRENT RESEARCH JOURNAL OF PHILOLOGICAL SCIENCES 2(8): 27-30,

May 2021 DOI: https://doi.org/10.37547/philological-crjps-02-08-07

ISSN 2767-3758

(C)2021 Master Journals

Crossref do: 81 Google

Accepted22 ${ }^{\text {th }}$ August, 2021 \& Published 27th August, 2021

Nolon kunim yupatgan sen,

Yuzing bosib yuzimga,

Singlim deymi,

Onam deymi,

Hamdardu - hamxonam deymi,

Oftobdan ham o'zing mehri,

Ilig'imsan vatanim.

Meaning:

On my happy day, you threw flowers at me,

You comforted my unhappy day,

By press your face to my face,

What do I say? Sister or mother,

Empathy - my roommate,

Your love is warmer than the sun,

My homeland.

In fact, there is no greater joy for a mother who sees her baby's first step. Like a mother, the homeland rejoices in the achievements and happy days of its people. Its paths are covered with flowering grasses. Like a sister, she is accompanied by sympathy in times of sadness. Apparently, the poet created verses based on simple life events with striking analogies and deep philosophical observation.

Another peculiarity of the poet's poems on the theme of the homeland is that the poet does not consider the homeland as an inanimate matter. Perhaps, in parallel with this, the driver of these objects - the nation, the people, together with the place where he was born and raised, considers the Homeland, and expresses in his works his boundless respect for this people, the nation. These eye-catching works, which reveal the mentality and traditions of the people, are very common in the work of the poet. For example, in the poem "Xalqona":

Qiz deganning ko'ksi to'la o'y bo'lar,

Yigit bir kun yetilib bo'y bo'ladi,

Bir tandir non o'rtada, bir kosa suv,

O'nta o'zbek yig'ilsa to'y bo'ladi.

Ro'yoblarga chiqadi shirin tushlar,

Kelinchakning yengidan kuyov ushlar,
Beshiklarni bo'shatib bir-biriga,

Tug'iladi To'maris, Alpomishlar.

Suyungandan onalar ko'zida yosh,

Otalar yuzida porlar quyosh.

Nabiralar to'ladi hovlilarga,

Bari bir xil - qora sochu - qora qosh,

Bola gapin yoqtirmas qaytganini,

Bizda bola qildirar aytganini,

Mayli sodiq o'ssa bas, yurtiga $\mathrm{u}$,

Boshlariga ko'tarib vatanini.

Dabdabasiz davralarda nur bo'ladi,

Kuyovto'ra, kelinchak hur bo'ladi.

Qayda yalla yangrasa kelavering,

O'zbegimning to'ylari zo'r bo'ladi.

Meaning:

The heart of a girl would be a full thought,

The young man will one day grow taller,

A loaf of bread in the middle, a bowl of water,

If ten Uzbeks gather, there will be a wedding.

Sweet dreams come true,

The bridegroom holds the bride's shirtsleeve,

Empty the cradles to each other,

Tomaris, Alpomish will born.

Tears in the eyes of happy mothers,

The sun shines on the father's face.

Grandchildren play in yards,

All the same - black hair - black eyebrows,

The child did not like their word not done,

In addition, the child makes to do what want in us,

It is enough if he grows faithful to own country,

To raise his country to the top.

There will be light in not lavish circles,

The bridegroom and the bride is free.

Wherever it sounds, come on,

My Uzbek wedding will be great.

Written in a unique melody, this poem captivates every reader and gives a rich impression of the uniqueness, traditions, simplicity and sincerity of the nation, in short, the mentality of the Uzbek people. That is why we consider Muhammad Yusuf's poetry to be international poetry. It is clear that in order to 
CURRENT RESEARCH JOURNAL OF PHILOLOGICAL SCIENCES 2(8): 27-30,

May 2021 DOI: https://doi.org/10.37547/philological-crjps-02-08-07

ISSN 2767-3758

(C)2021 Master Journals

Crossref dof 81 Google

Accepted22 ${ }^{\text {th }}$ August, 2021 \& Published 27th August, 2021

write works like Muhammad Yusuf about the homeland, people, nation, it is necessary to love and respect the homeland, the nation like Muhammad Yusuf, and for this, it is necessary to be born again as Muhammad Yusuf.

\section{REFERENCES}

1. Abdulla Avloni. Selected works. 2 volumes. Volume 1 - Tashkent.: "Ma'naviyat", 1998.

2. Narzullaev N. My people, my heart with you!: Poems, songs, quartets/ Responsible editor Azim Said. - Tashkent.: Yangi asr avlodi. 2000.-179 p.

3. Marufjon Yuldashev. Secrets of the word Cholpon. "Ma'naviyat", - Tashkent.: 2002.

4. Munavvar Qori Abdurashidkhonov. Selected works. - Tashkent.: "Ma'naviyat". $2003 \mathrm{y}$.

5. O'zbegim. Vatan series. "Sharq", - Tashkent .: 1992.

6. Muhammad Yusuf. Saylanma. (Selection). Tashkent. East. 2005.

7. Muhammad Yusuf. Xalq bo'l elim. (Be a nation, my people). Tashkent. Uzbekistan. 2005.

8. Muhammad Yusuf. Ulug'imsan Vatanim. (You are great, my country). Tashkent. Uzbekistan. 2010.

9. Muhammad Yusuf. Biz baxtli bo'lamiz (We will be happy). Tashkent. Nihol. 2008.

10. Usmanova, S. R. (2021). The Application of The Method of Metamorphosis In The Folklore of The Peoples of The East. Psychology and Education Journal, 58(1), 1033-1042.

11. Khudoyorovich, K. K., Rasuljanovna, I. N., Khalmuratovna, R. Z., \& Eshkobilovna, K. D. (2020). The Issues of Word Choice in Fiction Translation. International Journal of Psychosocial Rehabilitation, 24(04).

12. Ismatullayeva, N. R. Translation of phraseological units in Chinese and Uzbek languages. In Scientific research of the SCO countries: synergy and integration (International conference). Beijing, PRC, June (Vol. 24, pp. 45-50).

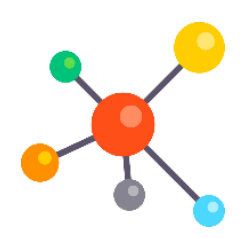

